\title{
THE DISCRIMINANT VALIDITY OF THE CULTURE ASSESSMENT INSTRUMENT: A COMPARISON OF COMPANY SUB-CULTURES
}

\author{
LEO PETKOON \\ GERT ROODT \\ Department of Human Resource Management \\ Rand Afrikaans University
}

\begin{abstract}
The primary purpose of this study was to assess the discriminant validity of the Culture Assessment Instrument (CAI); that is to distinguish between company mean sub-culture scores and between mean scores of a target company and that of a norm group. The primary data was obtained by a sample of convenience $(\mathrm{N}=593)$ from a transport organisation. The secondary data of the norm group was constituted by convenience samples $(\mathrm{N}=4066)$ from various companies originating from different industries. The 56 item scores of the CAI were factor analysed on two levels followed by iterative item analyses. Although significant differences were detected between mean culture scores, only a small proportion of the variance in these scores could be attributed to culture differences. On these grounds, the CAI does not possess discriminant validity. Suggestions for improving the CAI were made.
\end{abstract}

\section{OPSOMMING}

Die primêre doel van die studie was om die diskriminante geldigheid van die 'Culture Assessment Instrument' (CAI) te beoordeel; dit is om tussen ondernemings se gemiddelde kultuur-subtelling te onderskei en tussen die gemiddelde tellings van ' $\mathrm{n}$ teiken onderneming en 'n normgroep. Die primêre data is verkry van 'n geleentheidsteekproef $(\mathrm{N}=$ 593) uit 'n transport-onderneming. Die sekondêre data van die normgroep is saamgestel uit geleentheidsteekproewe $(\mathrm{N}=4066)$ van verskillende ondernemings afkomstig uit verskeie industrieë. Die 56 itemtellings van die CAI is op twee vlakke gefaktoranaliseer, gevolg deur iteratiewe itemontledings. Ofskoon beduidende verskille tussen gemiddelde kultuurtellings gevind is, kon slegs 'n klein proporsie van die variansie in die tellings aan kultuurverskille toegeskryf word. Op hierdie gronde beskik die CAI nie oor diskriminante geldigheid nie. Voorstelle ter verbetering van die CAI is gemaak.

\section{Organisational culture}

In the past 20 years or so, the concept of culture has become an important issue that has been heightened with the realisation that, through technology and markets, organisations are becoming increasingly global (Kobrin, in Joynt \& Warner, 1996).

Erwee, Lynch, Millett, Smith and Roodt (2001) very well summarise the current status in respect of organisational culture by stating that it remains one of the most contested areas of academic inquiry within the broader field of organisational studies. It is characterised by competing definitions, epistemologies and research paradigms. Controversies exist about virtually all aspects of this construct including the mechanics and extent of its contribution to organisational performance. However, there is considerable consensus about the importance of organisational culture.

In South Africa additional factors necessitate that organisations gain sound insight into their own cultures. South Africa is a highly heterogeneous society, consisting of many cultural groupings, which manifest in the work place. South Africa has been undergoing major transformation since becoming a democracy and being accepted as a full participant in the global economy. South Africa's success in the global economy will be positively or negatively affected by the ability of individual companies and industries to adapt their cultures to fit the global challenges, without losing their unique characteristics.

Organisational culture is the very fibre of the organisation. Thus the culture equates to the personality of the organisation (Kilmann, Saxton, Serpa \& Associates 1985), which can either facilitate or restrain change and performance. Differently stated, one can safely say that an organisation has successfully changed only after its culture has changed. For this reason it is crucial to fully understand the culture of the organisation, as well as how it develops and can be changed.

Requests for copies should be addressed to: G Roodt, Department of Human Resource Management, RAU University, PO Box 524, Auckland Park, 2006
The Culture Assessment Instrument (Martins, 1989) represents one line of inquiry in the field of organisational culture. Martins (1989, p. 45) defined organisational culture as follows:

\begin{abstract}
"Organisational culture is an integrated pattern of human behaviour, which is unique to a particular organisation and which originated as a result of the organisation's survival processes and interaction with its environment. Culture directs the organisation to goal attainment. Newly appointed employees must be taught what is regarded as the correct way of behaving."
\end{abstract}

The definition of Martins closely resembles the most commonly accepted definition of culture, i.e. the one by Schein $(1985$, p. 9):

"A pattern of basic assumptions - invented, discovered, or developed by a group as it learns to cope with its problems of external adaptation and internal integration - that has worked well enough to be considered valid and, therefore, to be taught to new members as the correct way to perceive, think and feel in relation to those processes."

Schein (1985) identified three levels of culture, i.e. artefacts, values and assumptions (See Figure 1). Insight into these levels are fundamental to understanding the culture of organisations.

Artefacts are visible, tangible and audible demonstration of behaviour supported by organisational norms, values and assumptions. Artefacts range from physical aspects such as architecture to forms of language to rituals. Values represent the principles and standards valued by organisational members. Values are the foundation as to what is acceptable and what is not acceptable. Assumptions and beliefs are the basis of an organisation's culture. Where solutions to a problem work continuously, the solution is used unconsciously and becomes the way things are done by the group. Assumptions are the basis for how organisational members think and feel. Assumptions are unconscious and are taken for granted (Schein, 1985).

To fully understand the complexity of the organisational culture literature, it is necessary to note the various perspectives of culture (Wilson, 2001). 

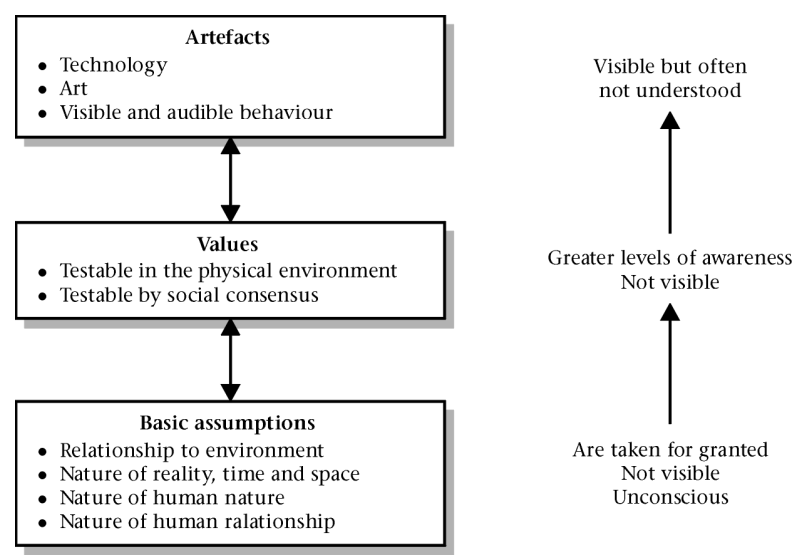

Figure 1: Schein's Levels of Culture

Adapted from Schein (1985, p.14)

Perspectives of Organisational Culture

Martin and Meyerson (1988) identified three major perspectives in organisational culture research, i.e. the integration perspective; the differentiation perspective, and the fragmentation perspective.

The integration perspective portrays a strong or desirable culture as one where there is organisation-wide consensus and consistency. Espoused values are consistent with formal practices, which are consistent with informal beliefs, norms and attitudes. Cultural members share the same values, promoting a shared sense of loyalty and commitment. Where inconsistencies, conflict or subcultural differentiation occur, this is portrayed as being a weak or negative culture.

The differentiation perspective emphasises that rather than consensus being organisation-wide, it only occurs within the boundaries of a subculture. At the organisational level, differentiated subcultures may co-exist in harmony, conflict or indifference to each other. Van Maanen (1991), in his study of an organisation, found groups of employees who considered themselves as being distinct. These sub-cultures related to different jobs, different levels of organisational status, gender and class. Claims of harmony from management masked a range of inconsistencies and group antagonisms. What is unique about a given organisation's culture, then, is the particular mix of subcultural differences within an organisation's boundaries.

The fragmentation perspective views ambiguity as the norm, with consensus and dissension co-existing in a constantly fluctuating pattern influenced by events and specific areas of decision making. As stated by Frost, Moore, Louis, Lundberg, and Martin (1991), consensus fails to coalesce on an organisation-wide or subcultural basis, except in transient, issuespecific ways. Rather than the clear unity of the integration perspective, or the clear conflicts of the differentiation viewpoint, fragmentation focuses on that which is unclear.

Many of the studies in organisational culture focus on only one of these perspectives, arguing whether it and it alone is evident within the organisation. Martin and Meyerson (1988) argued that any culture contains elements that can be understood only when all three perspectives are used. Therefore, within a company there may be organisation-wide consensus on some issues, consensus only within certain subcultures on other issues and an ambiguous state on the remainder. Schein, in Frost et al. (1991), suggested that there may be a core set of ideological guidelines within an organisation that require a minimal consensus and consistency, otherwise organisations would not function. Therefore consistency, consensus, harmony and integration may occur, but within the midst of inconsistencies, ambiguities, conflicts, disruption and dissolution.
Noting the complexities associated with the different perspectives described above, this study is carried out from the differentiation perspective, which emphasises that rather than consensus being organisation-wide, it only occurs within the boundaries of a subculture.

\section{Measuring Organisational Culture}

Although the concept of organisational culture has been prominent in organisational and management literature since the 1970s (Barley, Meyer, \& Gash, 1988), scholars still disagree on the best way to measure it (see O'Reilly, Chatman, \& Caldwell, 1991; Rousseau, 1990). Some authors have suggested the use of multiple methods (e.g., Martin, 1992; Rousseau, 1990), but these methods are often complex, expensive, and time-consuming (Ashkanasy, Broadfoot \& Falkus, 2000).

Among authors who suggest some use of quantitative measures are Amsa (1986), Barnett (1988), Bookbinder (1984), Cooke and Rousseau (1988), Desatnick (1986), Hofstede (1986), Reynierse (1986), Reynierse and Harker (1986), Reynolds (1986) and Wiener (1988).

Scholars such as Martin (1992) noted that quantitative assessment of organisational culture has been criticised in the past because of a strong mono-method bias in the field. Although Martin argues for a need to include qualitative data in culture studies, the essence of her case is that there is a need for a multilevel and multi-method conceptualisation. In this respect, Schein's (1985) three level typology provides a distinctive role for both quantitative and qualitative measurement.

As the elements of culture become more conscious and observable to participants in a study, they become more accessible to standardised assessment (Rousseau, 1990). For example, it is generally agreed that surveys represent an efficient and standardised means of tapping the shallower levels of Schein's typology. The deepest level of culture, on the other hand, can be investigated only through more intensive observation, focused interviews, and the involvement of organisational members in self-analysis (Ott, 1989; Rousseau, 1990; Schein, 1990). The thrust of this argument is that there is a clear and continuing role for quantitative measures as a means of assessing the less abstract levels of organisational culture.

All quantitative measures of culture are likely to suffer from the same limitations, with the main weakness being that basic assumptions are often non-debatable and unconscious. People's written or oral answers to questions are not necessarily indicative of their basic assumptions.

The usefulness of quantitative measurement may not be restricted to the shallower grounds for maintaining that the three levels of culture are unified especially when a culture is strong. In this case, quantitative measurement of organisational culture may have the potential to tap deeper levels of culture (Ott, 1989; Rentsch, 1990).

Ashkanasy et al. (2000) noted that survey methods have characteristics that render them especially useful for organisational culture research. Self-report surveys allow respondents to record their own perceptions of reality. Because behaviour and attitudes are determined not by objective reality but by actors' perceptions of reality (Rentsch, 1990), it is clearly appropriate to focus on perceptions rather than on reality. Further, self-report measures offer internal credibility to organisational members, which is likely to increase the likelihood that members will accept the results of the survey.

Researchers have cited numerous other advantages of survey assessment and of quantitative techniques generally. These include allowing replication and cross-sectional comparative studies, providing an accepted frame of reference for interpreting data, helping the evaluation and initiation of 
culture change efforts in organisations, and providing data that can be analysed through multivariate statistical techniques (Cooke \& Rousseau, 1988; Xenikou \& Furnham, 1996).

In summary, what is borne out by the literature, is that questionnaires can play an important role in the quantitative analysis of organisational culture (Reichers \& Schneider, 1990)

\section{A Need for Assessing Discriminant Validity}

Hofstede (1980) defined culture as the "collective programming of the mind, which distinguishes the members of one category of people from another." This definition stresses that culture is collective and not a characteristic of individuals (shared values); is interesting only to the extent that it differentiates between categories of people (Maull et al., 2001).

Yet, despite the fact that it's the differences in culture that makes it an interesting phenomenon, the literature review revealed that reporting on the ability of organisational culture instruments to assess cultural differences between companies is grossly neglected The literature often reports on the consensual, construct, and criterion validity of organisation culture instruments (Ashkanasy et al., 2000), but not the discriminant validity of the instruments. Hence, clearly there is a need to assess the discriminant validity of organisational culture instruments. This need is addressed in this study.

\section{METHOD}

The research participants

For this study two sets of data were used. The primary data were obtained from a sample drawn from the departments (seven) of a transport organisation. It yielded 593 responses (See Table 1). The secondary data set consists of a convenience sample of 4066 participants from five different organisations from various industries.

TABLE 1

RESPONSES PER DEPARTMENT

\begin{tabular}{lccc}
\hline Responses & Freq. & Percent & Cumul. \\
\hline Asset Life Cycle Management & 99 & 16,7 & 16,7 \\
Railway Engineering & 100 & 16,9 & 33,6 \\
Evaluation, Acquisition and Review & 32 & 5,4 & 39,0 \\
Traction & 88 & 14,8 & 53,8 \\
Wagons & 70 & 11,8 & 65,6 \\
Governance & 16 & 2,7 & 68,3 \\
Infrastructure Maintenance & 188 & 31,7 & 100,0 \\
Total & 593 & 100,0 & 100,0 \\
\hline
\end{tabular}

Table 2 provides a brief overview of the biographical properties of the respondents in the survey sample and the norm group. From Table 2 it can be inferred that the majority of respondents in the survey sample are white, male, and in the age group $36-$ 45 , whilst the majority of respondents in the norm group are white, male, Afrikaans speaking and in the age group $25-35$. Broadly speaking the attributes of the survey sample and the norm group are very similar.

\section{The measuring instrument}

The items included in the measuring instrument (Culture Assessment Instrument) were developed by Martins (1989). The original questionnaire, the Organisational Culture Survey consisted of 89 items. However, only 56 items (renamed as the Culture Assessment Instrument), common to all the organisations in the sample of the secondary data set, were included in the study. These 56 items are proportionally representative of the six dimensions of the questionnaire. The overall reliability (Cronbach Coefficient Alpha) of the instrument is 0,933 . The internal consistencies of the dimensions vary between 0,655 and 0,932 .

TABLE 2

BIOGRAPHICAL VARIables

\begin{tabular}{|c|c|c|c|c|}
\hline \multirow[b]{2}{*}{ Category } & \multirow{2}{*}{$\begin{array}{r}\text { NORM GROUP } \\
\text { Count }\end{array}$} & \multirow[b]{2}{*}{$\%$} & \multicolumn{2}{|c|}{$\begin{array}{c}\text { TRANSPORT } \\
\text { ORGANISATION }\end{array}$} \\
\hline & & & Count & $\%$ \\
\hline \multicolumn{5}{|l|}{ RACE } \\
\hline White & 1086 & $44,9 \%$ & 409 & $69 \%$ \\
\hline Coloured & 294 & $12,2 \%$ & 19 & $3,2 \%$ \\
\hline Indian & 125 & $5,2 \%$ & 21 & $3,5 \%$ \\
\hline Black & 912 & $37,7 \%$ & 144 & $24,3 \%$ \\
\hline Total & 4066 & $100 \%$ & 593 & $100 \%$ \\
\hline \multicolumn{5}{|l|}{ AGE } \\
\hline 24 and younger & 438 & $11,3 \%$ & 8 & $1,3 \%$ \\
\hline $25-35$ & 1808 & $46,5 \%$ & 166 & $28,0 \%$ \\
\hline $36-45$ & 1006 & $25,9 \%$ & 186 & $31,4 \%$ \\
\hline 46 and more & 638 & $16,4 \%$ & 233 & $39,3 \%$ \\
\hline Total & 4066 & $100 \%$ & 593 & $100,0 \%$ \\
\hline \multicolumn{5}{|l|}{ GENDER } \\
\hline Male & 2034 & $52,0 \%$ & 512 & $86,3 \%$ \\
\hline Female & 1876 & $48,0 \%$ & 81 & $13,7 \%$ \\
\hline Total & 4066 & $100 \%$ & 593 & $100,0 \%$ \\
\hline \multicolumn{5}{|l|}{ LANGUAGE } \\
\hline Afrikaans & 1014 & $80,5 \%$ & * & * \\
\hline English & 225 & $17,9 \%$ & * & * \\
\hline Other & 21 & $1,7 \%$ & * & * \\
\hline Total & 4066 & $100 \%$ & * & * \\
\hline
\end{tabular}

The theoretical model, which underpins the CAI, is depicted in Figure 2. According to Martins (1989) an organisation is a complex social system in which individual and group activities take place. The various subsystems together form the culture of the organisation. Organisational culture influences the behaviour of employees, suppliers and customers as well as the organisation's relationship with the community. Culture has an effect on the internal as well as the external environment and is in turn influenced by both environments. The reason being that the organisation has to continuously adapt to the external environment. In order for the organisation to adapt to the external environment its internal processes have to change and adapt on a continuous basis.

From Figure 2 it can be seen that the model consists of three main elements, i.e. the organisational system, survival functions and dimensions of culture.

The organisational system consists of five subsystems i.e., goal-, technical-, structural-, psychosocial-, and management subsystem. These five subsystems form the internal subsystem. The external system consists of the environment in which the organisation operates. The organisation thus has to stay abreast of shareholders, customers, competitors, the community, as well as political, statutory, economic and ecological factors. The way, in which all the external factors are dealt with, could have a major impact on the success and survival of the organisation. As a result of the interaction and reciprocal influence of the various subsystems on one another, a unique culture is created in each organisation, which makes it unique and distinguishes it from other organisations. 


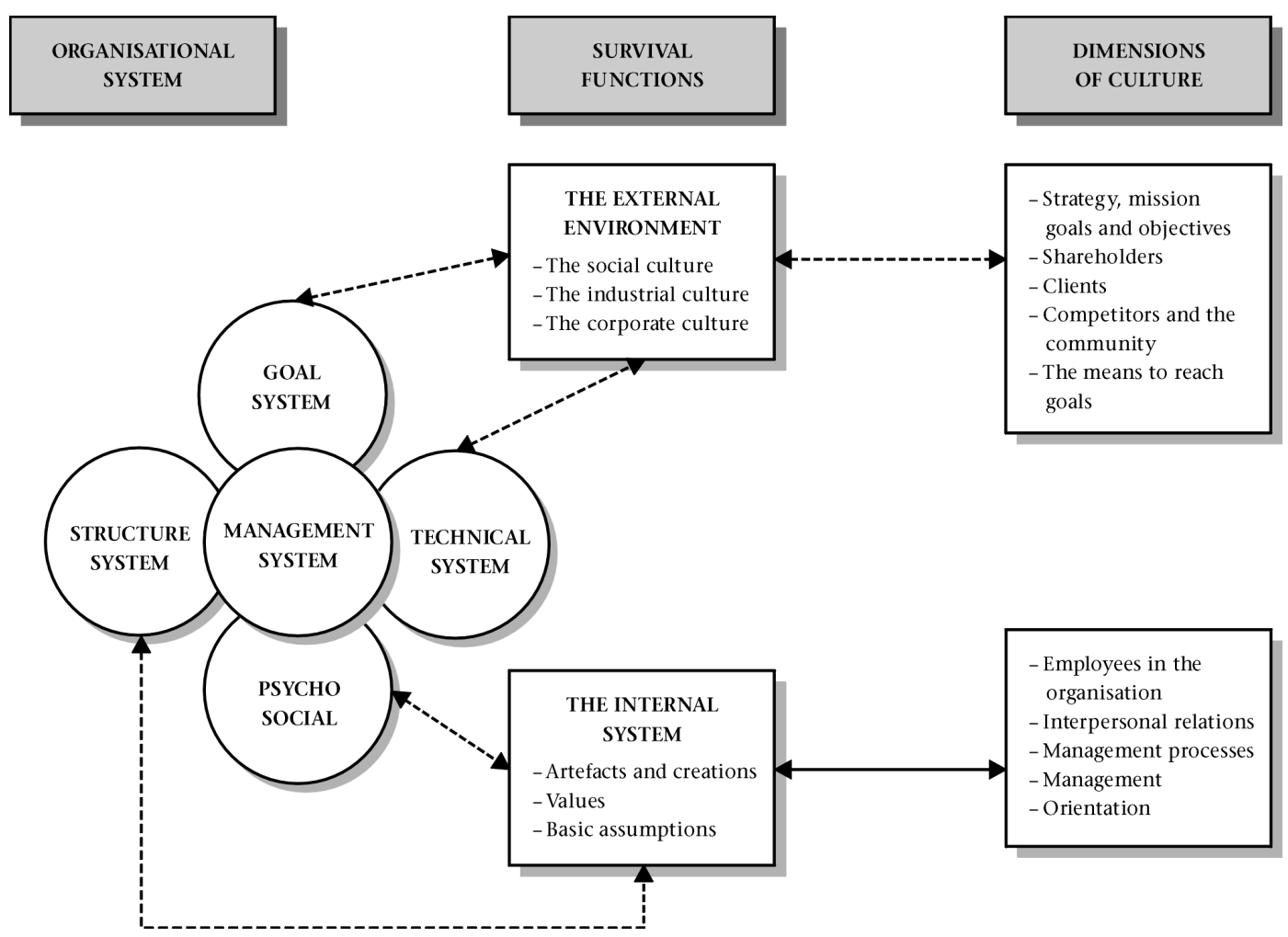

Figure 2: A Model of Organisational Culture (Martins, 1989, p.92)

From Figure 2 it is clear that the two main variables that must be taken into account in assessing the culture of an organisation are the problems of survival and adaptation of the organisation to the (a) external environment and (b) the internal organisational system.

Dimensions of culture are subdivided into two categories, i.e. those that relate to the external environment and those that relate to the internal environment (See Figure 2). Dimensions relating to the external environment are:

a) Strategy, mission, goals and objectives;

b) Shareholders, customers, competitors and community; and

c) The means to reach goals.

Dimensions relating to the internal environment are:

a) Employees in the organisation;

b) Interpersonal relations;

c) Management processes; and

d) Management orientation.

\section{The research procedure}

The primary data set was obtained from a sample drawn from a transport organisation, whilst the secondary data set was built from data gathered from participating organisations over the last few years. The primary and secondary data were originally gathered mainly with a view to improve the performance of the specific organisations. The main difference between the analysis of organisational culture between the primary and secondary data is that the organisations in the secondary data were also researched by means of interviews and focus groups to analyse the deeper levels of organisational culture. The aim of gathering the information was thus the same in all the cases.

\section{Statistical analysis}

The statistical procedures were selected for their suitability to test the research hypotheses of the study. These procedures include descriptive statistics, factor analyses and analyses of variance. In respect of factor analyses a procedure developed by
Schepers (1992) was followed. This procedure includes first as well as second levels factor analyses. The Statistical Consultation Service of the Rand Afrikaans University conducted the analyses. All calculations were done by means of the SPSS- Windows program of SPSS - International.

\section{RESULTS}

First level factor analysis on the inter-correlation matrix The 56 items of the Culture Assessment Instrument were intercorrelated and rotated to a simple structure by means of the Varimax rotation. Owing to limited space, the intercorrelation matrix (56 x 56) is not reproduced here.

Twelve factors were postulated according to Kaiser's (1961) criterion (eigenvalues-greater-than-unity) and extracted by means of a principal factor analysis, also called Principal Axis Factoring.

The factor matrix obtained was rotated to simple structure by means of Varimax rotation. The twelve factors explain about $60 \%$ of the variance in the factor space. Subsequently, sub-scores (SS) were calculated on the twelve obtained factors and they were subjected to a second level factor analysis.

Second level factor analysis on the inter-correlation matrix The twelve sub-scores (obtained from the first factor analysis) were inter-correlated and the results of the inter-correlation of the sub-scores are displayed in Table 3.

During second level factor analysis two factors were extracted by means of a principal factor analysis according to Kaiser's (1961) criterion (eigenvalues-greater-thanunity). Table 4 provides the eigenvalues of the unreduced factor matrix. From Table 4 it can be seen that these two factors explained about $58 \%$ of the variance in the factor space. 
TABLE 3

MATriX OF INTER-CORRELATIONS OF 12 SUb-SCORES (SS)

\begin{tabular}{|c|c|c|c|c|c|c|c|c|c|c|c|c|}
\hline & S1 & S2 & S3 & S4 & S5 & S6 & S7 & S8 & S9 & S10 & S11 & S12 \\
\hline SS1 & 1,000 & & & & & & & & & & & \\
\hline SS2 & 0,678 & 1,000 & & & & & & & & & & \\
\hline SS3 & 0,669 & $0,651(* *)$ & 1,000 & & & & & & & & & \\
\hline SS4 & 0,698 & $0,637(* *)$ & $0,586(* *)$ & & & & & & & & & \\
\hline SS5 & 0,591 & $0,580(* *)$ & $0,497\left(^{* *}\right)$ & $0,569(* *)$ & 1,000 & & & & & & & \\
\hline SS6 & 0,564 & $0,586(* *)$ & $0,511\left(^{* *}\right)$ & $0,519(* *)$ & $0,500(* *)$ & 1,000 & & & & & & \\
\hline SS7 & 0,403 & $0,384(* *)$ & $0,393(* *)$ & $0,469(* *)$ & $0,413(* *)$ & $0,340\left(^{* *}\right)$ & 1,000 & & & & & \\
\hline SS8 & 0,635 & $0,587\left(^{* *}\right)$ & $0,652(* *)$ & $0,578\left(^{* *}\right)$ & $0,471(* *)$ & $0,469(* *)$ & $0,412(* *)$ & 1,000 & & & & \\
\hline SS9 & 0,505 & $0,486\left(^{* *}\right)$ & $0,488\left(^{* *}\right)$ & $0,497\left(^{* *}\right)$ & $0,455(* *)$ & $0,383(* *)$ & $0,332(* *)$ & $0,420\left(^{* *}\right)$ & 1,000 & & & \\
\hline SS10 & 0,345 & $0,264(* *)$ & $0,265(* *)$ & $0,421(* *)$ & $0,292(* *)$ & $0,289\left(^{* *}\right)$ & $0,438\left(^{* *}\right)$ & $0,373(* *)$ & $0,254(* *)$ & 1,000 & & \\
\hline SS11 & 0,151 & $0,185(* *)$ & $0,084\left(^{*}\right)$ & $0,173\left(^{* *}\right)$ & $0,184\left(^{* *}\right)$ & $0,142(* *)$ & $0,138\left(^{* *}\right)$ & $\left.0,147^{* *}\right)$ & $0,102\left(^{*}\right)$ & $0,185\left(^{* *}\right)$ & 1,000 & \\
\hline SS12 & 0,538 & $0,547\left(^{* *}\right)$ & $0,506(* *)$ & $0,579(* *)$ & $0,355\left(^{* *}\right)$ & $0,418\left(^{* *}\right)$ & $0,290(* *)$ & $0,452(* *)$ & $0,438(* *)$ & $0,207(* *)$ & 0,072 & 1,000 \\
\hline
\end{tabular}

* * Correlation is significant at the 0.01 level (2-tailed)

* Correlation is significant at the 0.05 level (2-tailed).

$\mathrm{N}=593$

TABLE 4

Eigenvalues of THE UnREDUCED INTER-CORRELATION MATRIX OF SUBSCORES EXPLAINED

\begin{tabular}{lccc}
\hline \multicolumn{3}{c}{ Initial Eigenvalues } \\
Root & Eigenvalue & \% of Variance & Cumulative \% \\
\hline $\mathbf{1}$ & 5,858 & 48,819 & 48,819 \\
$\mathbf{2}$ & 1,103 & 9,191 & 58,010 \\
$\mathbf{3}$ & 0,893 & 7,443 & 65,453 \\
$\mathbf{4}$ & 0,659 & 5,489 & 70,942 \\
$\mathbf{5}$ & 0,641 & 5,338 & 76,280 \\
$\mathbf{6}$ & 0,566 & 4,719 & 80,999 \\
$\mathbf{7}$ & 0,550 & 4,580 & 85,578 \\
$\mathbf{8}$ & 0,479 & 3,988 & 89,566 \\
$\mathbf{9}$ & 0,343 & 2,857 & 92,424 \\
$\mathbf{1 0}$ & 0,333 & 2,776 & 95,200 \\
$\mathbf{1 1}$ & 0,307 & 2,555 & 97,755 \\
$\mathbf{1 2}$ & 0,269 & 2,245 & 100,000 \\
\hline
\end{tabular}

Trace $=12$

TABLE 5

SORTED AND Rotated FACtor MATRIX of Subscores

\begin{tabular}{lccc}
\hline Sub Scores & \multicolumn{2}{c}{ Factor } & 2 \\
\hline SS2 & 0,878 & \\
SS3 & 0,834 & \\
SS1 & 0,830 & \\
SS12 & 0,707 & \\
SS4 & 0,679 & \\
SS8 & 0,645 & \\
SS6 & 0,635 & \\
SS5 & 0,597 & \\
SS9 & 0,591 & \\
SS10 & & \\
SS7 & & 0,791 \\
SS11 & & 0,222 \\
\hline
\end{tabular}

The sorted and rotated factor matrix appears in Table 5. Scale One represents Culture excluding Opportunity and Scale Two is referred to as "Opportunity". For convenience sake Scale One will generally be referred to as "Culture".

The sub-scores on the CAI data set were subsequently forced into a one factor solution to enable comparison with the norm group. The factor matrix for the one factor solution appears in Table 6 .

TABLE 6

Sub-SCore LoAdings on a Single Forced Factor

\begin{tabular}{lcc}
\hline Sub Scores & $\mathbf{1}$ & Factor \\
& SS1 & $\mathbf{h}^{2}$ \\
\hline SS4 & 0,841 & 0,707 \\
SS2 & 0,818 & 0,670 \\
SS3 & 0,807 & 0,651 \\
SS8 & 0,771 & 0,595 \\
SS5 & 0,739 & 0,547 \\
SS6 & 0,690 & 0,475 \\
SS12 & 0,667 & 0,444 \\
SS9 & 0,631 & 0,398 \\
SS7 & 0,612 & 0,374 \\
SS10 & 0,541 & 0,293 \\
SS11 & 0,439 & 0,193 \\
\end{tabular}

Extraction Method: Principal Axis Factoring.

a 1 factors extracted. 4 iterations required.

An iterative item analysis procedure was conducted on the scales 1 and 2 as well as the single scale and high Cronbach Coefficients Alpha of 0,954;0,707 and 0,953 were respectively obtained. Table 7 provides the item statistics for the single scale.

Analyses of variance: comparison of internal sub-cultures and comparison with the norm group

In order to test Hypothesis 1, which states that there are significant differences in mean culture scores between the subcultures based on demographic variables of the transport organisation, and Hypothesis 2, which states that there are significant differences in mean culture scores between subcultures based on various functional departments of the transport organisation, a multivariate analysis of variance was conducted on the two scales. 
TABLE 7

Reliability Analysis - Scale (Alpha)

\begin{tabular}{|c|c|c|c|c|}
\hline & $\begin{array}{c}\text { Scale Mean } \\
\text { if Item } \\
\text { Deleted }\end{array}$ & $\begin{array}{l}\text { Scale Variance } \\
\text { if Item } \\
\text { Deleted }\end{array}$ & $\begin{array}{c}\text { Corrected } \\
\text { Item - Total } \\
\text { Correlation }\end{array}$ & $\begin{array}{l}\text { Alpha if } \\
\text { Item } \\
\text { Deleted }\end{array}$ \\
\hline Q2 & 170,162 & 891,011 & 0,436 & 0,953 \\
\hline Q3 & 170,798 & 875,121 & 0,589 & 0,952 \\
\hline Q4 & 170,570 & 874,874 & 0,592 & 0,952 \\
\hline Q5 & 170,911 & 874,007 & 0,559 & 0,952 \\
\hline Q6 & 170,892 & 878,174 & 0,469 & 0,953 \\
\hline Q7 & 170,263 & 880,367 & 0,509 & 0,953 \\
\hline Q8 & 170,767 & 884,368 & 0,413 & 0,953 \\
\hline Q10 & 170,690 & 886,444 & 0,475 & 0,953 \\
\hline Q11 & 170,474 & 885,344 & 0,579 & 0,953 \\
\hline Q12 & 170,499 & 879,933 & 0,534 & 0,953 \\
\hline Q13 & 170,465 & 888,378 & 0,384 & 0,953 \\
\hline Q14 & 170,592 & 877,793 & 0,526 & 0,953 \\
\hline Q15 & 170,374 & 878,164 & 0,484 & 0,953 \\
\hline Q19 & 171,044 & 875,738 & 0,511 & 0,953 \\
\hline Q20 & 171,086 & 877,555 & 0,452 & 0,953 \\
\hline Q21 & 170,562 & 885,328 & 0,419 & 0,953 \\
\hline Q23 & 171,390 & 878,647 & 0,409 & 0,953 \\
\hline Q24 & 171,218 & 880,116 & 0,530 & 0,953 \\
\hline Q25 & 171,634 & 881,756 & 0,413 & 0,953 \\
\hline Q26 & 170,499 & 895,521 & 0,203 & 0,954 \\
\hline Q27 & 170,897 & 884,873 & 0,409 & 0,953 \\
\hline Q28 & 171,933 & 883,678 & 0,492 & 0,953 \\
\hline Q29 & 170,673 & 879,619 & 0,519 & 0,953 \\
\hline Q30 & 170,796 & 878,933 & 0,521 & 0,953 \\
\hline Q31 & 170,842 & 877,725 & 0,555 & 0,953 \\
\hline Q33 & 170,793 & 883,188 & 0,513 & 0,953 \\
\hline Q34 & 170,648 & 877,323 & 0,645 & 0,952 \\
\hline Q37 & 171,064 & 876,378 & 0,584 & 0,952 \\
\hline Q38 & 170,577 & 873,785 & 0,617 & 0,952 \\
\hline Q40 & 170,968 & 868,453 & 0,711 & 0,952 \\
\hline Q44 & 171,477 & 878,355 & 0,565 & 0,952 \\
\hline Q45 & 170,889 & 875,910 & 0,552 & 0,953 \\
\hline Q46 & 171,196 & 877,354 & 0,491 & 0,953 \\
\hline Q47 & 170,631 & 882,993 & 0,460 & 0,953 \\
\hline Q49 & 170,880 & 875,808 & 0,613 & 0,952 \\
\hline Q50 & 170,159 & 883,282 & 0,539 & 0,953 \\
\hline Q51 & 171,300 & 877,342 & 0,578 & 0,952 \\
\hline Q53 & 170,988 & 873,606 & 0,642 & 0,952 \\
\hline Q55 & 170,096 & 888,253 & 0,478 & 0,953 \\
\hline Q56 & 170,127 & 889,351 & 0,451 & 0,953 \\
\hline Q58 & 170,619 & 877,108 & 0,578 & 0,952 \\
\hline Q59 & 170,110 & 890,936 & 0,395 & 0,953 \\
\hline Q61 & 169,366 & 904,790 & 0,196 & 0,954 \\
\hline Q63 & 170,639 & 878,718 & 0,554 & 0,953 \\
\hline Q64 & 171,464 & 884,357 & 0,408 & 0,953 \\
\hline Q66 & 170,361 & 890,525 & 0,462 & 0,953 \\
\hline Q67 & 170,363 & 880,123 & 0,588 & 0,952 \\
\hline Q68 & 170,533 & 884,638 & 0,473 & 0,953 \\
\hline Q69 & 170,702 & 877,700 & 0,539 & 0,953 \\
\hline Q70 & 170,557 & 881,234 & 0,517 & 0,953 \\
\hline Q71 & 169,858 & 891,774 & 0,357 & 0,953 \\
\hline Q72 & 170,772 & 876,798 & 0,617 & 0,952 \\
\hline Q73 & 170,705 & 875,073 & 0,639 & 0,952 \\
\hline Q74 & 170,496 & 875,896 & 0,617 & 0,952 \\
\hline Q75 & 170,405 & 878,819 & 0,602 & 0,952 \\
\hline Q76 & 170,567 & 877,189 & 0,633 & 0,952 \\
\hline
\end{tabular}

Reliability Coefficients

$\mathrm{N}$ of Cases $=593$

$\mathrm{N}$ of Items $=56$

Alpha $=0,953$
In order to test hypothesis 3 , which states that there are significant differences in mean culture scores between the transport organisation and organisations in the norm group, an univariate analysis of variance was conducted on the scores of the single scale.

The main findings, based on the results of the analyses of variance, summarised in Table 8 , are:

- Respondents with less than 10 year's service are more positive than respondents with more than 10 years service about opportunities in the organisation.

- Respondents in the age group 46-54 are least positive, whilst respondents in the age group 36-45 are most positive about the culture of the division.

- Respondents in the age groups 46 years and older feel negative about opportunity, while respondents in the age group 45 years and younger feel positive about opportunity in the company.

- Females are significantly more positive than males in respect of both culture and opportunity in the company.

- Blacks are positive about opportunity, while whites are negative about opportunity in the company.

- Management is negative about opportunity, while junior officials are positive, although not highly positive about opportunity.

- Governance is significantly more positive about culture than the rest of the departments.

- Governance is significantly more positive than the rest of the departments about opportunity,

It must be kept in mind that the above findings are based on the significance of differences in variance between groups, the percentage of variance attributable to differences in culture scores are in most cases very low or nearly insignificant in proportion, based on Partial Eta Squared. The percentage of variance explained in all these findings varies between $2 \%$ and $8 \%$ with one exception, i.e. the variable "race" on Scale 2 , in which case $17 \%$ of the variance is explained.

Based on above findings Hypothesis 1, which states there are significant differences in mean culture scores between the subcultures based on demographic variables of the transport organisation as well as Hypothesis 2, which states that there are significant differences in mean culture scores between subcultures based on various functional departments of the transport organisation, are rejected. These findings imply that the Culture Assessment Instrument (consisting of 56 items) only possess very limited internal discriminant validity, because only very small proportions of variance could be accounted for.

In comparing the culture of the transport organisation with the organisations in the norm group further analyses were conducted to counter the effects of sample size. The statistical procedures carried out for this purpose, are the Chi-square and the Partial Eta Squared. The results of these statistics revealed that there are significant differences in mean culture scores, but only $1,5 \%$ of the variance could be explained after provision was made for difference in sample size. Based on these results Hypothesis 3, which states that there are significant differences in mean culture scores between the transport organisation and organisations in the norm group, is also rejected.

\section{DISCUSSION}

It is clear from the factor and the item analyses that the construction of the CAI is based on a number of sound psychometric principles. The CAI complies with most of the criteria, which according to Schepers (1992) as cited in Swart, 
TABle 8

Analysis of Variance: Comparison of InTERnal Sub-Cultures

\begin{tabular}{|c|c|c|c|c|c|c|c|c|c|c|c|c|}
\hline \multirow[b]{3}{*}{ Scale } & \multirow{3}{*}{$\begin{array}{l}\text { LEVENE'S } \\
\text { F-Ratio }\end{array}$} & \multirow{3}{*}{$\begin{array}{c}\text { TEST } \\
\text { Df1 }\end{array}$} & \multirow[b]{3}{*}{ Df2 } & \multirow[b]{3}{*}{$\mathrm{P}(\mathrm{F})$} & \multirow[b]{3}{*}{ Df } & \multicolumn{4}{|l|}{ ANOVA } & \multirow[t]{2}{*}{ POST HOC } & \multicolumn{2}{|l|}{ TEST } \\
\hline & & & & & & \multicolumn{4}{|c|}{ Partial Eta Squared } & & \multicolumn{2}{|c|}{ Mean Difference } \\
\hline & & & & & & F-Ratio & $\mathbf{P}(\mathrm{F})$ & & (1) & (J) & $(\mathrm{I}-\mathrm{J})$ & (P) \\
\hline \multicolumn{13}{|c|}{ Tenure } \\
\hline 1 & 1,365 & 1 & 591 & 0,243 & 1 & 0,175 & 0,676 & 0,000 & & & & \\
\hline 2 & 3,719 & 1 & 591 & 0,054 & 1 & 52,586 & 0,000 & 0,082 & & & & \\
\hline \multicolumn{13}{|l|}{ Age } \\
\hline 1 & 3,027 & 3 & 589 & 0,029 & 3 & 4,243 & 0,006 & 0,021 & $36-45$ & $46-54$ & $0,208^{*}$ & 0,003 \\
\hline \multirow[t]{4}{*}{2} & 0,898 & 3 & 589 & 0,442 & 3 & 14,258 & 0,000 & 0,068 & $<35$ & $46-54$ & $0,392^{*}$ & 0,000 \\
\hline & & & & & & & & & $<35$ & $\geq 55$ & $0,367 *$ & 0,002 \\
\hline & & & & & & & & & $36-45$ & $46-54$ & $0,298^{*}$ & 0,000 \\
\hline & & & & & & & & & $36-45$ & $\geq 55$ & $0,274^{*}$ & 0,034 \\
\hline \multicolumn{13}{|c|}{ Gender } \\
\hline 1 & 0,133 & 1 & 591 & 0,715 & 1 & 19,429 & 0,000 & 0,032 & & & & \\
\hline 2 & 3,603 & 1 & 591 & 0,058 & 1 & 16,422 & 0,000 & 0,027 & & & & \\
\hline \multicolumn{13}{|l|}{ Race } \\
\hline 1 & 13,492 & 1 & 493 & 0,000 & 1 & 1,527 & 0,217 & 0,003 & & & & \\
\hline 2 & 1,272 & 1 & 493 & 0,260 & 1 & 101,922 & 0,000 & 0,171 & & & & \\
\hline \multicolumn{13}{|c|}{ Grade } \\
\hline 1 & 1,692 & 2 & 590 & 0,185 & 2 & 2,028 & 0,132 & 0,007 & & & & \\
\hline \multirow[t]{2}{*}{2} & 4,986 & 2 & 590 & 0,007 & 2 & 5,285 & 0,005 & 0,018 & Jnr Off & Snr Mng & $0,189^{*}$ & 0,021 \\
\hline & & & & & & & & & Jnr Off & Jnr Mng & $0,164^{*}$ & 0,017 \\
\hline \multicolumn{13}{|c|}{ Department } \\
\hline \multirow[t]{3}{*}{1} & 6,505 & 6 & 586 & 0,000 & 6 & 3,515 & 0,002 & 0,035 & Governance & EAR & $0,543^{*}$ & 0,035 \\
\hline & & & & & & & & & Governance & Traction & $0,654^{*}$ & 0,004 \\
\hline & & & & & & & & & Governance & Infra & $0,518^{*}$ & 0,028 \\
\hline 2 & 2,370 & 6 & 586 & 0,029 & 6 & 3,174 & 0,005 & 0,031 & & & & \\
\hline
\end{tabular}

* The mean difference is significant at the 0.05 level

Roodt and Schepers (1999) are important in constructing a questionnaire:

- The construct "culture" is theoretically clearly founded.

- There is no doubt about which domain the construct belongs to, i.e. "organisational culture"

- Sub domains were identified, i.e. Mission/Vision; Management Processes; Employee Needs and Objectives; External Environment; Means to Achieve Objectives; and Interpersonal Relations.

- Behavioural indicators were identified for the sub domains. These behavioural indicators were used to link the theoretical concepts with the empirical variables.

The one criterion that was somewhat neglected is item format. Item format is important to ensure that the questions support the behavioural indicators. Item format covers aspects such as the correct use of language, questions versus statements, the type of response scale and the instructions of the instrument. The correct use of these elements influences the validity of the questionnaire. In the construction of the CAI these guidelines were not strictly applied.

As far as the questionnaire response scale is concerned, the questionnaire uses a 5-point Likert response scale where all the response categories are labelled. According to Schepers (1992) the equal interval quality of a scale is lost if more than two points are anchored. Schepers (1992) recommended that it is better to use an intensity response scale where only the two extreme categories are labelled as depicted in Figure 3.

\begin{tabular}{|c|c|c|c|c|}
\hline 1 & 2 & 3 & 4 & 5 \\
\hline
\end{tabular}

Figure 3: Proposed Intensity Response Sale

The factor analyses resulted in two robust factors that indicate a fairly sound theoretical basis as well as a sound procedure in the construction of the CAI. This assumption is supported by a high internal consistency of 0,953 . This indicates a high reliability and only a limited amount of error variance in the measurement of the construct "organisational culture".

The results of the analysis of variance revealed that there are differences in mean culture scores between the demographic variables and the departments in the transport organisation and between the transport organisation and the norm group. However, only a limited portion of these differences could be attributed to differences in cultures.

However, based on the literature review, a priori differences in cultures between demographic variables and departments and organisations, especially if they are from various industries, were postulated. The CAI did not detect these differences. It can thus be inferred that the instrument does not possess the ability to distinguish differences in sub-cultures in an organisation or in cultures between organisations from different industries. These findings suggest that the CAI lacks discriminant validity. 
On the other hand the CAI reliably assessed commonalities in culture between organisations. This is the strength of the instrument. It is good at detecting commonalities between entities. See Figure 4 for a graphic representation of what the findings suggest. In Figure 4 each circle represents a different entity and the shaded area represents the similarities between the entities, as identified by the instrument. The areas not shaded represent the unique differences between the entities, not identified by the instrument.

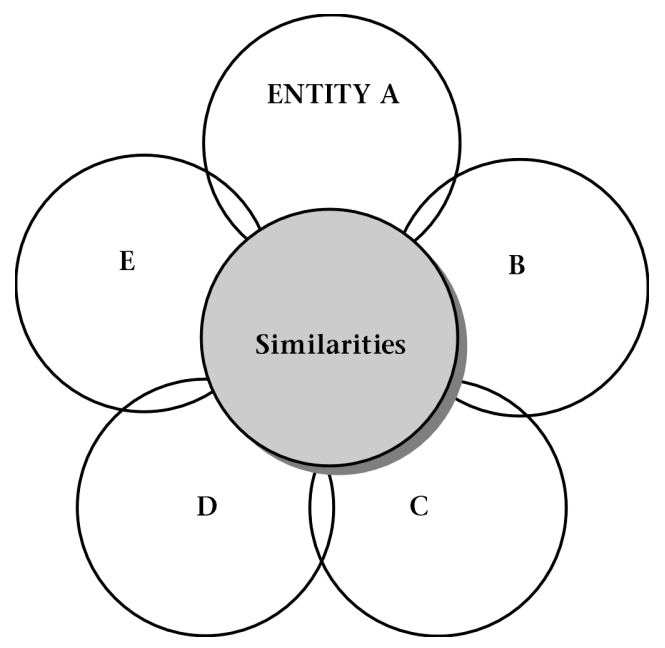

Figure 4: Similarities between Entities

These commonalities, however, are mainly at surface level - the level of artefacts and creations with reference to Schein's (1985) three-level typology (See Figure 1). At this level entities may appear to have the same culture. The reason for this phenomenon is that organisations are quick to embrace the latest management tools and practices in their striving to keep up with the fast changing business environment. There is a possibility that the instrument detected these practices which are common to all organisations.

In sum, the instrument identifies similarities at surface level but not differences at the deeper levels. The scale was designed for the tangible, espoused level (the level of practice if you wish) but not for the deeper (unconscious) level of tacit values and basic assumptions. Inferences can be made about the deeper levels, but the items in the instrument did not purposefully and systematically expose the deeper levels of organisational culture.

Emanating from the findings of the literature and the empirical research it is recommended that further research be undertaken to operationalise the construct organisational culture at the deeper levels, which are, the levels of tacit values, taken for granted assumptions and basic beliefs. The authors believe that with proper operationalisation at the more fundamental levels it will be possible to successfully distinguish cultures between entities from the positivistic paradigm.

Finally, It is recommended that the application of the Culture Assessment Instrument be supplemented with methods from the interpretative paradigm for a holistic and comprehensive view on the culture of an organisation.

\section{ACKNOWLEDGEMENT}

- The authors are indebted to Prof Nico Martins of Organisational Diagnostics for providing the data set for conducting this research. The 56-item CAI used in this research was abstracted from a larger item pool collected across various organisations and does not constitute the original Organisational Culture Survey of Prof Martins. Data collected from each organisation by means of the Survey was supplemented by qualitative methods.

- The authors would like to thank Riëtte Eiselen and her staff from Statcon at RAU for their professional service and valuable contribution regarding the data analysis for this project.

\section{REFERENCES}

Ajiferuke, M. \& Boddewyn, J. (1970). Socioeconomic indicators in comparative management. Administrative Sciences Quarterly, December, 453-458.

Amsa, P. (1986). Organizational culture and work group behaviour: an empirical study. Journal of Management Studies (UK), 23 (3), 347-62.

Ashkanasy, N.M., Broadfoot, L.E. \& Falkus, S. (2000a). Questionnaire measures of organizational culture. In Ashkanasy, N.M., Wilderom, C.P.M. \& Peterson, M.F. (Eds.), Handbook of organizational culture and climate. California: Sage Publications, Inc.

Ashkanasy, N.M., Wilderom, C.P.M. \& Peterson, M.F. (Eds.)(2000b), Handbook of organizational culture and climate. California: Sage Publications, Inc.

Barley, S. R., Meyer, G. W., \& Gash, D. C. (1988). Cultures of culture: Academics, practitioners and the pragmatics of normative control. Administrative Science Quarterly, 33, 24-60.

Barnett, G.A. (1988). Communication and organizational culture. In Goldhaber, G.M. \& Barnett, G.A. (Eds), The handbook of organizational communication (101-30). Ablex, Norwood.

Beyer, J.M., Hannah, D.R. \& Milton, L.P. (2000). Ties that bind: culture and attachments in organisations. In Ashkanasy, N.M., Wilderom, C.P.M. \& Peterson, M.F. (Eds), Handbook of organizational culture \& climate (323-338). California: Sage Publications, Inc.

Bolman, L. \& Deal, T. (1991). Reframing organisations: artistry, choice and leadership. San Francisco, CA.: Jossey-Bass Publishers.

Bookbinder, S.M. (1984). Measuring and managing corporate culture. Human Resource Planning, 7 (1), 47-53.

Cooke, R.A. \& Rousseau, D.M. (1988). Behavioural norms and expectations: A quantitative approach to the assessment of organizational culture. Group and Organization Studies, 13, September, 245-73.

Denison, D.R. (1996). What is the difference between organizational culture and organizational climate? A native's point of view on a decade of paradigm wars. Academy of Management Review, 21, 619-654.

Desatnick, R.L. (1986). Management climate surveys: a way to uncover an organization's culture. Personnel, 63 (5), 49-54.

Erwee, R., Lynch, B., Millett, B., Smith, D. \& Roodt, G. (2001). Cross-cultural equivalence of the organisational culture survey in Australia. Journal of Industrial Psychology, 27 (3), 7-12.

Frost, P.J., Moore, L., Louis, M., Lundberg, C. \& Martin, J. (Eds) (1991), Reframing organisational culture. Beverly Hills, CA: Sage Publications.

Gabriel, Y. (1991), Turning facts into stories and stories into facts: a hermeneutic exploration of organizational folklore. Human Relations, 44 (8), 857-75.

Hofstede, G. (1980). Culture's consequences. Beverly Hills, CA: Sage.

Hofstede, G. (1986). Editorial: The usefulness of the 'organizational culture' concept. Journal of Management Studies, 23 (3), May, 253-57.

Joynt, P. \& Warner, M. (Eds) (1996). Managing across cultures. London: Thomson Business Press.

Kaiser, H.F. (1961). A note on Guttman's lower bound for the number of common factors. British Journal of Statistical Psychology, 14 (1), 1. 
Kilmann, R., Saxton, M., Serpa, R. \& Associates (1985). Gaining control of the corporate culture. San Francisco: Jossey-Bass.

Kroeber, A. \& Kluckhohn, F. (1952). Culture: A critical review of concepts and definitions, Cambridge, Mass.: Harvard Business Review.

Martin, J. \& Meyerson, D. (1988). Organisational culture and the denial, channelling and acknowledgement of ambiguity. In Pondy, L.R., Boland, Jr., R.J. \& Thomas, H. (Eds), Managing ambiguity and change. New York. NY: John Wiley \& Sons.

Martin, J. (1992). Cultures in organizations: Three perspectives. New York: Oxford University Press.

Martins, N. (1989). Organisasiekultuur in 'n finansiële instelling (D.Philproefskrif). Pretoria: University of Pretoria. (Unpublished).

Maull, R., Brown, P. \& Cliffe, R. (2001). Organisational culture and quality improvement. International Journal of Operations \& Production Management, 21 (3), 302-326.

Nossiter, V. \& Biberman, G. (1990). Projective drawings and metaphor: analysis of organisational culture. Journal of Managerial Psychology (UK), 5 (3)13-6.

O'Reilly, C. A., III, Chatman, J. A., \& Caldwell, D. F. (1991). People and organizational culture: A profile comparison approach to assessing person-organization fit. Academy of Management Journal, 34, 487-516.

Ott, J.S. (1989). The organisational culture perspective. Chicago: Dorsey Press.

Reichers, A. E., \& Schneider, B. (1990). Climate and culture: An evolution of constructs. In B. Schneider (Ed.), Organizational climate and culture (5-39). San Francisco: Jossey-Bass.

Rentsch, J. R. (1990). Climate and culture; Interaction and qualitative differences in organizational meanings. Journal of Applied Psychology, 75, 668-681.

Reynierse, J.H. \& Harker, J.B. (1986). Measuring and managing organizational culture. Human Resource Planning, 9 (1), 1-8.
Reynierse, J.H. (1986). Measuring corporate culture. The Business Magazine, September - October, 64-67.

Reynolds, P.D. (1986). Organizational culture as related to industry, position and performance: a preliminary report. Journal of Management Studies (UK), Vol. (23), 333-45.

Rousseau, D.M. (1990). Assessing organizational culture: The case for multiple methods. In B. Schneider (Ed.), Organizational climate and culture (153-192). San Francisco: Jossey-Bass.

Schein, E.H. (1985). Organizational culture and leadership: A dynamic view. San Francisco, CA: Jossey-Bass.

Schein, E.H. (1990). Organizational culture. American Psychologist, 45, 109-119.

Schepers, J.M. (1992). Toetskonstruksie: Teorie en praktyk. Johannesburg: RAU Press.

Swart, C., Roodt, G., \& Schepers, J.M. (1999). Itemformaat, differensiële itemskeefheid en die faktorstruktuur van ' $\mathrm{n}$ selfvoltooiingsvraelys. Tydskrif vir Bedryfsielkunde, 25 (1), 33-43.

Tucker, R.W., McCoy, W.J. \& Evans, L.C. (1990). Can questionnaires objectively assess organisational culture? Journal of Managerial Psychology (UK), 5 (4), 4-11.

Van Maanen, J. (1991). The smile factory: work at Disneyland. In Frost, P.J., Moore, L., Louis, M., Lundberg, C. \& Martin, J. (Eds). Reframing organisational culture. Beverly Hills, CA: Sage Publications.

Wiener, Y. (1988), Forms of value systems: a focus on organizational effectiveness and cultural change and maintenance. Academy of Management Review, 13 (4), 534-45.

Wilson, A. M. (2001). Understanding organisational culture and the implications for corporate marketing. European Journal of Marketing, 35 (3/4), 353-367.

Xenikou, A., \& Furnham, A. (1996). A correlational and factor analytic study of four questionnaire measures of organizational culture. Human Relations, 49 (349-371). 